\title{
Two Rebt Therapists and One Client: Windy Dryden Transcript
}

\author{
Windy Dryden
}

Published online: 12 June 2010

(C) Springer Science+Business Media, LLC 2010

\begin{abstract}
In the summer of 1994, two of the most published authors in the field of Rational Emotive Behavior Therapy (REBT), Albert Ellis and Windy Dryden, each saw the same client. The transcript of Windy Dryden is presented with slight modifications to protect the confidentiality of the client and those in the client's life.
\end{abstract}

Keywords REBT $\cdot$ Transcript $\cdot$ Decison-making

1 Two REBT Therapists and One Client: Windy Dryden Transcript

$2 \mathrm{~W}$ : OK. So, why don't you start where you want to?

$3 \mathrm{~J}$ : Well, um, I'm conflicted about...ah, whether or not to live with L. I'm married and I have been for 21 years. I just thought I was happily married, until L came around, and he kind of got me questioning a lot of things.

$4 \mathrm{~W}$ : How did he do that?

$5 \mathrm{~J}$ : Um...just by saying are you happily married? And I said yes. And then...um... just made me think about it. I guess I hadn't thought about it before. But I'm very, very much in love with him and um...he wants me to live with him and I'm conflicted because of my kids.

$6 \mathrm{~W}$ : How old are your kids?

$7 \mathrm{~J}$ : I have (teenagers). And conflicted because also because my social circle of friends and my kids it all kind of revolves around the religion. And my kids would not...um...think it was a very good idea if I was living with somebody.

W. Dryden (ه)

Goldsmiths University of London, New Cross, London SE14 6NW, UK

e-mail: windy@thedrydens.clara.net 
$8 \mathrm{~W}$ : Right. Do they know about L?

$9 \mathrm{~J}: \quad$ Mm hmm.

$10 \mathrm{~W}$ : What do they think about it?

$11 \mathrm{~J}$ : Um. They think... he's the exact opposite of my husband, you know. My husband is very straight, and you can see that L is very unconventional. Um. They don't know him, they just have seen him.

$12 \mathrm{~W}$ : Right. And does your husband know about him?

$13 \mathrm{~J}: \quad$ Yes.

$14 \mathrm{~W}$ : And how does he feel about that?

$15 \mathrm{~J}: \quad$ Um. Well my husband doesn't like him...(laughs)... Um and my husband thinks that I...since L is so much the opposite of him that that is like a total rejection of him.

$16 \mathrm{~W}$ : OK. And how long have you been with L?

$17 \mathrm{~J}: \quad$ Um about seven months.

$18 \mathrm{~W}$ : Seven months. Right. And it's ...do you see him fairly regularly?

$19 \mathrm{~J}: \quad$ Mm hmm. Yeah.

$20 \mathrm{~W}$ : And he wants to live with you? Does he want to get married to you or does he just want to live with you?

$21 \mathrm{~J}: \quad$ Well. He doesn't...it wouldn't bother him if we didn't get married. But he would marry me. He said he would. But, he doesn't think the marriage thing...it's not that big a deal. Although, he was married for several years, until, um, his wife (had an accident).

$22 \mathrm{~W}: \quad$ And?

$23 \mathrm{~J}$ : Died.

$24 \mathrm{~W}$ : Oh, and died. You seem pretty tearful at the moment.

$25 \mathrm{~J}$ : Tearful? ... (W: Yeah) ... It's the thought of my kids, you know. Not having anything to do with me. Because of $\mathrm{L}$ and living with him.

$26 \mathrm{~W}$ : That's your fear is it?

$27 \mathrm{~J}: \quad$ Uh huh.

$28 \mathrm{~W}$ : So you have a fear, that if you went to your kids, and you said, "Look, I'm going to be living with L," they'll say what?

$29 \mathrm{~J}$ : They'd probably say, "Well, you don't have to come around here anymore. We don't care to see you."

$30 \mathrm{~W}$ : And as you look at that, how?...

$31 \mathrm{~J}: \quad$ I mean, it's my whole circle of friends too. It's all the ... religion.

$32 \mathrm{~W}$ : Right. So you're not only losing contact with your kids but you'd be losing the whole contact with the ... religion.

$33 \mathrm{~J}$ : $\quad$ Mm hmm.

$34 \mathrm{~W}$ : I don't know much about the ... religion. What's...

$35 \mathrm{~J}$ : $\quad$ It's very strict.

$36 \mathrm{~W}$ : What's its view on divorce and people living with....

$37 \mathrm{~J}: \quad$ They, I mean it's definitely, you don't live with someone unless you're married.

$38 \mathrm{~W}$ : And knowing your friends in the religion, would they reject you do you think? 
$39 \mathrm{~J}: \quad$ Um, probably. At least to a certain degree.

$40 \mathrm{~W}$ : Would some reject you more than others?

$41 \mathrm{~J}: \quad \mathrm{Mm}$ hmm.

$42 \mathrm{~W}$ : Do you think that some of your friends would stand by you?

$43 \mathrm{~J}$ : Maybe a little bit. But not like, I don't think we would have as close a friendship as I have with them now.

$44 \mathrm{~W}$ : So you really do have a lot to lose. What do you have to gain?

$45 \mathrm{~J}$ : Just L and...I don't know. I love him a whole bunch, I don't think I've ever felt like this before about anyone, including my husband. Um, and...

$46 \mathrm{~W}$ : I noticed before, when I asked you that question, that your face lit up.

$47 \mathrm{~J}: \quad \mathrm{Mm}$ hmm.

$48 \mathrm{~W}$ : Did you notice that?

$49 \mathrm{~J}: \quad$ I really love him. A whole lot. And I...

$50 \mathrm{~W}$ : How would you feel if you...are you in a situation whereby, it's a situation that you really have to choose either...

$51 \mathrm{~J}: \quad$ It's going to have to be either or.

$52 \mathrm{~W}$ : Yeah. Right.

$53 \mathrm{~J}: \quad$ I'm pretty darn sure.

$54 \mathrm{~W}$ : Well. What we do in Rational Emotive Behaviour Therapy in these situations, is look at the two poles, the two alternatives, help you to be as rational as you can be about the two, then or even perhaps first, help you over your... any fears that you have about indecisiveness, because you've got to...you have a choice to make right? And you're also maybe indecisive. Would you say you are...

$55 \mathrm{~J}$ : Do I have trouble making decisions? Is that what you mean?

$56 \mathrm{~W}$ : Yeah.

$57 \mathrm{~J}: \quad$ Um.

$58 \mathrm{~W}$ : Or just in this area?

$59 \mathrm{~J}: \quad$ I think just in this area. Pretty much.

$60 \mathrm{~W}$ : How do you feel about the fact that at the moment you're not able to make a decision that easily? How do you feel about....

$61 \mathrm{~J}: \quad$ Well, it's uncomfortable.

$62 \mathrm{~W}$ : Uh huh. Just uncomfortable or....

$63 \mathrm{~J}$ : Um. I don't like it.

$64 \mathrm{~W}$ : Right...But it sounds as if you're not disturbing yourself about the fact that you are not making a decision...

$65 \mathrm{~J}$ : Yeah. But I'm going to have to make a decision. I mean, when I go home from here, I'm going to have to make a decision, either move in with $\mathrm{L}$, or.

$66 \mathrm{~W}$ : Right so it's as imminent as that?

$67 \mathrm{~J}: \quad$ Yeah.

$68 \mathrm{~W}$ : We're talking about over the next few days.

$69 \mathrm{~J}: \quad$ Yeah. 
$70 \mathrm{~W}$ : Yeah. Okay. Let's suppose you actually chose to stay with your kids, and the (religious group), you know and stay with your husband. Now, that would mean losing L. Right? How would you feel about that?

$71 \mathrm{~J}: \quad$ Devastated.

$72 \mathrm{~W}$ : Meaning what?

$73 \mathrm{~J}: \quad$ I don't know. Life wouldn't be too enjoyable I guess.

$74 \mathrm{~W}$ : Mm hmm. It wouldn't be enjoyable, but that doesn't equate to being devastated does it? I mean...

$75 \mathrm{~J}: \quad$ No.

$76 \mathrm{~W}$ : So what do you think you've been telling yourself about....

$77 \mathrm{~J}$ : $\quad$ It would be very hurtful not to have $\mathrm{L}$ around.

$78 \mathrm{~W}$ : In what sense?

$79 \mathrm{~J}: \quad$ Um. He makes me feel very loved.

$80 \mathrm{~W}$ : So you would lose something that's very important to you, something you feel loved about. OK. But in our therapy, it's not just that loss that leads to the devastation. It's your attitude towards the loss. Now what do you think your attitude towards that loss would be?

$81 \mathrm{~J}$ : Um. I'd be very, very sad.

$82 \mathrm{~W}$ : But that's healthy, because sadness is: "Look, I'm losing something that's very important to me, that is very sad", but, there's always a but here, but you know face it. It's not the end of the world. I would be able to survive and have some happiness, not as much as perhaps, you know, as much as I'd have with him, but it wouldn't be the end of the world. Would you say that you were kind of adding that 'it will be the end of the world' aspect to this?

$83 \mathrm{~J}: \quad$ Yeah. Probably.

$84 \mathrm{~W}$ : Now. Would it be the end of the world?

$85 \mathrm{~J}: \quad$ Well, yeah it would.

$86 \mathrm{~W}$ : OK. Are you open to looking at that? OK. Let's suppose ... I give you another scenario, alright. Let's suppose L died. OK. Now do you think you'd ever get over that loss?

$87 \mathrm{~J}: \quad$ I wouldn't have a choice.

$88 \mathrm{~W}:$ So...

$89 \mathrm{~J}: \quad$ I would have to.

$90 \mathrm{~W}$ : OK. Let's suppose it would be a year after his death. How would you feel?

$91 \mathrm{~J}: \quad$ I'd probably still be missing him.

$92 \mathrm{~W}$ : But, where would you be in your life? Would you be missing him and be miserable, you know crying, shutting people away, or would you be starting to regroup and move on?

$93 \mathrm{~J}: \quad$ I'd probably be regrouping. I guess. I am a survivor.

$94 \mathrm{~W}$ : OK. Right. You are a survivor. If we bring that into the picture, OK, which said, look "If I lost L, by choosing to go with the (religious group) and my children, that's tremendously sadful (sic!), but, it's not the end of 
the world. I'm a survivor, and I can move on". Does that kind of bring a different flavour to it or not?

$95 \mathrm{~J}: \quad$ Yeah.

$96 \mathrm{~W}: \quad$ Yea.

$97 \mathrm{~J}: \quad \mathrm{Mm}$ hmm.

$98 \mathrm{~W}$ : OK. So now if you can start to think more rationally, which includes feeling very sad, rational thinking means that you're going to feel very sad about losing L. Let's go the other route. Let's suppose you choose L. Now how would you feel about, and let's take the worst, your children say: "Mum, as far as we are concerned, we have no mother" and the (religious group) say "As far as we're concerned, we don't know you." Now, how would you feel about that?

$99 \mathrm{~J}: \quad$ That would bother me a whole bunch.

$100 \mathrm{~W}$ : What would the feeling be?

$101 \mathrm{~J}: \quad$ Mainly my kids.

$102 \mathrm{~W}$ : OK. Let's stick to the kids. How would you feel about your kids saying that?

$103 \mathrm{~J}$ : Um. I would feel devastated.

$104 \mathrm{~W}$ : Again, it's not the loss of the kids, which again is going to feel very, very sad. No taking away from that, but what would you be adding, what would you be bringing to that loss that would lead to the devastation?

$105 \mathrm{~J}$ : That I couldn't stand it.

$106 \mathrm{~W}$ : What couldn't you stand about them saying that?

$107 \mathrm{~J}$ : Um. I don't know, it's...they're my kids. You know. I love them.

$108 \mathrm{~W}$ : Mm hmm. And therefore....

$109 \mathrm{~J}$ : I don't want to lose them.

$110 \mathrm{~W}$ : You don't want to lose them, right, but we have to help you to look at the worst, you know, right in the face. Right? And say, could you tolerate that rejection?

$111 \mathrm{~J}$ : I could probably tolerate it. But I wouldn't like it.

$112 \mathrm{~W}$ : That's not your goal. Your goal is not to say 'Hey, my kids rejected me, who cares' or "My kids have rejected me, I don't mind." You see. You're going to feel very sad. But the point is our theory says that you're saying something very healthy, which is, "I've lost something that's very important to me. My kids, they've have rejected me. I can't stand it, and it's terrible". Now, let me put something to you that you might find strange. Right? Would you leave your kids if it meant it was the only way of keeping them alive?

$113 \mathrm{~J}: \quad$ Yeah.

114 W: You'd never see them again, but they're alive. Right. How would you feel then?

$115 \mathrm{~J}$ : If it saved their lives, I would gladly do that.

$116 \mathrm{~W}$ : But how would you feel about losing them?

$117 \mathrm{~J}$ : I would be sad. 
$118 \mathrm{~W}$ : So you see what I'm saying here. It's not just the losing them, it's losing them plus the construction, which is "I couldn't stand it". But if you couldn't stand it, you'd have to condemn them to death. You see what I'm saying? Let me just see if I'm making myself clear. Can you just run that past me? What do you think I'm saying?

$119 \mathrm{~J}$ : OK. If the only way to keep them alive was to leave them and never see them again I would gladly do that, even though I would feel very sad, I would at least know they were okay. They were alive.

$120 \mathrm{~W}$ : Even though you never saw them again.

$121 \mathrm{~J}: \quad$ But I could stand that.

$122 \mathrm{~W}$ : They don't know. They think that you've rejected them. Alright. They don't know...

$123 \mathrm{~J}$ : Oh, don't! Why'd you throw that in?

$124 \mathrm{~W}$ : Because it's important isn't it?

$125 \mathrm{~J}$ : Yes.

$126 \mathrm{~W}$ : OK. They think you've rejected them, but you know you're keeping them alive. How would you then feel?

$127 \mathrm{~J}$ : I guess I could stand that, knowing that it was keeping them alive.

$128 \mathrm{~W}$ : Right, so, I'm putting this to you. I wonder if your real problem is that you're doing it for you? You're putting you first. Is that an issue for you? I'm putting myself first, my happiness first....

$129 \mathrm{~J}$ : Probably.

$130 \mathrm{~W}$ : Is that in there? And how do you feel about that?

$131 \mathrm{~J}: \quad$ Selfish.

$132 \mathrm{~W}$ : And what's the feeling that goes along with the selfishness?

$133 \mathrm{~J}$ : Putting myself down for putting myself first.

$134 \mathrm{~W}$ : I'm hearing a big ' $G$ '. Do you know what the big ' $G$ ' is? Begins with ' $G$ '. $135 \mathrm{~J}$ : No.

$136 \mathrm{~W}$ : You're feeling the guilt.

$137 \mathrm{~J}$ : Oh! The guilt.

$138 \mathrm{~W}$ : Is that in there?

$139 \mathrm{~J}: \quad$ Feeling guilty. Yeah.

$140 \mathrm{~W}$ : Now, guilt, in Rational Emotive Behaviour Therapy is saying, you're doing the wrong thing, right? I'm a bad person for doing the wrong thing, cos I'm being selfish, right? Is that how you would feel?

$141 \mathrm{~J}: \quad$ Yeah. Uh huh.

$142 \mathrm{~W}$ : Now. How would you be a bad person for doing this, let's suppose, a selfish thing.

$143 \mathrm{~J}: \quad$ Well, I wouldn't be a bad person.

$144 \mathrm{~W}$ : You wouldn't be a bad person?

$145 \mathrm{~J}: \quad$ No.

$146 \mathrm{~W}$ : Why wouldn't you be a bad person?

$147 \mathrm{~J}$ : I would be happy, but I'd be conflicted still.

$148 \mathrm{~W}$ : Yeah. Right. And you're going to be conflicted, you see. Now, do you think there may be something here about, 'I really have to make a 
decision without experiencing the conflictedness?' Is that in there at all?

$149 \mathrm{~J}: \quad$ Um. No, I really don't think so.

$150 \mathrm{~W}$ : No? It's not in there, Ok. So, if I can help you, to first of all take the horror out of losing L. Right, and then take the horror out of losing your kids, right, so that you're saying, "Look, if I lose L that would be very sad, but it's not the end of the world, I can move on. And again, if I lose my kids that would be very bad, but again on the end of the world, I can move on. I would not be a bad person, even if I look at it as if it is selfish". But selfishness in my book means only putting yourself first and not really giving a damn about other people.

$151 \mathrm{~J}: \quad$ And so, I do give a damn, otherwise I wouldn't be conflicted.

$152 \mathrm{~W}$ : That's right. Exactly. If you left your kids, it would be because, you are doing it because it would be enlightened self interest, but, and this is a big but, you can't make a decision without feeling that you are breaking some important principle. You can't because you've got the principle of "I love L, I don't want to lose him", and the principle of "I love my kids and I don't want to lose them". You see. So whatever you do you're going to break a principle. It's inevitable. You see what I'm saying?

$153 \mathrm{~J}:$ Yeah.

$154 \mathrm{~W}$ : So, if you accept that then here's what we do. Lets suppose, right- how old are you now?

$155 \mathrm{~J}: \quad 42$.

$156 \mathrm{~W}$ : Right. You're on your deathbed. Right, imagine that. You're on your deathbed. You've stayed with the kids and the (religious group), and you've left L. Right. Now how do you feel about that decision, on your deathbed?

$157 \mathrm{~J}: \quad$ Like I cheated myself.

$158 \mathrm{~W}$ : You cheated yourself. Ok. Now you're on your deathbed, you've gone with $\mathrm{L}$, and the worst has happened. The kids have rejected you, and the community's rejected you. Ok. But you're with L. How do you feel on your deathbed?

$159 \mathrm{~J}: \quad$ Is L gonna stick around? (laughs)

$160 \mathrm{~W}$ : Let's suppose that, because I think that's another element here.

$161 \mathrm{~J}: \quad$ It is. That's a big element.

$162 \mathrm{~W}$ : Ok. We'll come to it in a minute, OK?

$163 \mathrm{~J}: \quad \mathrm{Um}$.

$164 \mathrm{~W}$ : How do you feel about it if he stuck around?

$165 \mathrm{~J}$ : I would feel like I was missing out on a whole world of kids, grandkids, and I missed out.

$166 \mathrm{~W}$ : Right.

$167 \mathrm{~J}$ : And so I cheated myself again.

$168 \mathrm{~W}$ : Right. Which of these two situations would you rather be in? Being on your deathbed, saying "I've cheated myself because I've missed out on the only man who I really felt something strongly for". Or "I've cheated 
myself because I've missed out on a whole world of kids and grandkids and the community". Which of the two situations would you prefer to be in? You've only got one bed! You have to choose.

$169 \mathrm{~J}: \quad$ That's well, that's kind of my problem.

$170 \mathrm{~W}$ : I know, but which of the two would you like to....

$171 \mathrm{~J}$ : I feel that ...oh gosh......

$172 \mathrm{~W}$ : If you don't chose one of them, there'll be no bed and you're going to burn in hell, so you have to choose. (Laughs)

$173 \mathrm{~J}$ : That's hard...that's my whole problem. I want it all.

$174 \mathrm{~W}$ : Right. So we come back to two other issues. Right. Why do you have to have it all?

$175 \mathrm{~J}$ : Well, just because I want it. I desire it.

$176 \mathrm{~W}$ : Alright! And of course you run the universe don't you! I see. Ok. Do you have to have it all?

$177 \mathrm{~J}: \quad$ No.

$178 \mathrm{~W}$ : Why not?

$179 \mathrm{~J}: \quad$ I mean I would survive without having it both ways.

$180 \mathrm{~W}$ : Right.

$181 \mathrm{~J}$ : I'm going to have to.

$182 \mathrm{~W}$ : Right...Let's suppose that we gave you a guarantee that L would never leave you. Right. Would that make a difference to you?

$183 \mathrm{~J}$ : Yeah.

$184 \mathrm{~W}$ : What difference would it make?

$185 \mathrm{~J}$ : It would be easier to choose him.

$186 \mathrm{~W}$ : Yeah. And would you choose him?

$187 \mathrm{~J}: \quad$ Probably.

$188 \mathrm{~W}$ : Probably, right. So let's have a look at this other thing. Your fear is, that you choose him, and down the line, what happens?

$189 \mathrm{~J}: \quad$ He doesn't love me.

$190 \mathrm{~W}$ : Right.

$191 \mathrm{~J}: \quad$ And he leaves.

192 W: Right. Now, what do you think you're saying about that?

$193 \mathrm{~J}$ : I have to have his love, and I don't have to have...

194 W: No, but you're also saying "Shit, I've lost L and...I've given up my kids! I'm alone, I've-

$195 \mathrm{~J}$ : - lost everything.

$196 \mathrm{~W}$ : I've lost everything. Right. Now. Is that something that you could live with?

$197 \mathrm{~J}$ : I could but it would be very, very difficult. VERY.

$198 \mathrm{~W}$ : But you could choose him, and he could die.

$199 \mathrm{~J}$ : I know.

$200 \mathrm{~W}$ : Because, aren't you demanding a guarantee? Aren't you really saying, "Jesus, if I go with this guy, he has to a) stay alive, and b) love me. He's got to promise me this, and keep the promise." Ok. Does he have to do that? 
$201 \mathrm{~J}: \quad$ No.

$202 \mathrm{~W}$ : Why not?

$203 \mathrm{~J}$ : Because there are no guarantees. Nobody can guarantee things like that.

204 W: Right. Now let's have a look at a scenario. You've chosen him, he's gone off, he's left you, right. Your kids don't want you back. How would you construct a life for yourself?

$205 \mathrm{~J}$ : I would have to...um...reach out and meet new people.

206 W: Right. Remember, you're a survivor. Right. How does that seem? It'd be difficult wouldn't it?

$207 \mathrm{~J}: \quad$ I could do it.

208 W: You could do it. Right. So if you take...Let's just go over what we've talked about, today. First of all, you need to take the horror out of losing L on the one scenario and the horror out of losing the kids. Not the sadness. You will be very sad, whatever you've done. Whatever you decide to do, you're going to be sad. It's important to give up the demand that you have to have it all. And also the demand for a guarantee that if you choose L he's going to stay around and love you.

$209 \mathrm{~J}: \quad \mathrm{Mm} \mathrm{mmh}$.

$210 \mathrm{~W}$ : Keep in touch with that image of being a survivor is really important. What do you think about those ideas?

$211 \mathrm{~J}$ : Yeah. I mean if I can keep that in perspective. I am a survivor. And I'm going to feel sad no matter which way I go. But there are no guarantees my kids are going to be around anyway either. And I mean they're not...they're going to...

$212 \mathrm{~W}$ : That's right.

$213 \mathrm{~J}$ : They're going to leave and have their own lives.

$214 \mathrm{~W}$ : And there's no guarantee that after a while - that you're not going to reform a relationship after they grow up. You don't know that. But we have to deal with the worst you see, because that's what you're thinking about.

$215 \mathrm{~J}$ : Right.

$216 \mathrm{~W}$ : Right. So, there are no guarantees. Does that help you in making a decision?

$217 \mathrm{~J}$ : Yeah.

$218 \mathrm{~W}$ : In what way?

$219 \mathrm{~J}$ : I think I'm really going to have to go with L.

$220 \mathrm{~W}$ : Okay. But now I'm going to help you to prepare. I'll be the irrational voice and you answer me back. 'You're a selfish woman. What kind of woman would really reject her kids like that?"

$221 \mathrm{~J}$ : The kind of woman that is really crazy in love with L and wants to grab for the happiness while she has it available.

$222 \mathrm{~W}$ : "But what a selfish person you are. How can you do that? Your poor kids. They need a mother."

$223 \mathrm{~J}$ : They've had a mother (into their teenage) years. They've had... I mean, I've been there the whole while. 
$224 \mathrm{~W}$ : Let me play...lets go from a different point of view. "But how can you trust that man. Look at him! He's a hippy. He's you know...he's..."

$225 \mathrm{~J}$ : $\quad$ He is that.

$226 \mathrm{~W}$ : "You can't trust hippies, you know he might be zooming off. I mean how many other relationships has he had since his wife died?"

$227 \mathrm{~J}: \quad$ Plenty.

$228 \mathrm{~W}$ : "Yeah! How do you know you're not going to be the one that's going to be next on the cast-off list?"

$229 \mathrm{~J}: \quad$ I don't know. I don't know that.

$230 \mathrm{~W}$ : "But you need to know, you need to know, you've gotta know. How could you possibly make a decision without knowing?"

$231 \mathrm{~J}$ : Well. You have to because there are no guarantees. I mean there are no guarantees. And if I want to grab for this happiness I have to know that there are no guarantees that he's going to be around. And I can't look back after I do it.

$232 \mathrm{~W}$ : You can look back, but when you look back...you see when you look back, you're going to look back by ....it's important to look back in terms of the decisions you've made. So you are going to look back and regret the fact that you've lost your kids and you need to really affirm the reason why you've chosen L.

$233 \mathrm{~J}$ : But there's a lot of negatives that go with choosing L too and that's what ....makes the decision....

$234 \mathrm{~J}$ : Um...Do we have time?

$235 \mathrm{~W}$ : I think so.

$236 \mathrm{~J}$ : He's in debt big time. He is a substance abuser. Big time. Um and he's promised...he's not on the drug thing, but whenever he gets angry with me he goes back to it.

$237 \mathrm{~W}$ : So maybe you need to get a commitment from him that so, you know, a commitment that ....Do you really have to make a decision right now? I mean, there's pressure...

$238 \mathrm{~J}: \quad$ Yeah from L.

$239 \mathrm{~W}$ : But why do you have to go along with his pressure?

$240 \mathrm{~J}$ : I think if I don't make a decision to live with him when I go back home from New York, um, he probably will just say: That's it."

$241 \mathrm{~W}$ : OK. Now what do you make of that? Here's a man who's in big time debt, and abusing substances, he's asking you to make a damn big commitment without making a commitment to you. What commitment would you like from him that would help you to make a decision?

$242 \mathrm{~J}$ : That he would stay away from abusing drugs and that he will stick around with me.

$243 \mathrm{~W}$ : Well, why don't you ask for that commitment? But, a commitment of time. That perhaps he's got to be clean for what, how long?

$244 \mathrm{~J}: \quad$ A year.

$245 \mathrm{~W}$ : Is he in a treatment programme?

246 J: No. But he... 
$247 \mathrm{~W}:$ Maybe he needs to get into a treatment programme right?

$248 \mathrm{~J}$ : Well, but he does that.

$249 \mathrm{~W}$ : He's in a treatment programme but he still abuses?

$250 \mathrm{~J}$ : No, he runs, he does the Rational...

$251 \mathrm{~W}$ : Who cares? He still....he's still abusing substances. Now my point is to you, he's asking you to make a commitment - big commitment to leave your kids- don't you also have the right to actually ask for something from him?

$252 \mathrm{~J}$ : I would say I do, but then we just did this great big talk with...nobody has any rights.

$253 \mathrm{~W}$ : I'm not talking about rights in the absolute sense, I'm talking about right in the sensible sense.

$254 \mathrm{~J}$ : Since he's asking me to make a commitment I can feel okay with asking him to make a commitment.

$255 \mathrm{~W}$ : Yeah. It's a commitment in ... I mean if you were ... if I was in this situation with you and you were ... I would say to you "I need to know that you're going to be off these blasted drugs for a decent amount of time, and that the first time that we have an argument, you're not going to rush back and take the drugs. I don't need to know....but this is my bottom line, hadn't you better ask yourself, what kind of commitment am I going to be asking from him to do before I make this leap.

$256 \mathrm{~J}$ : Mm mmh. That's a very, very good...idea. Very good.

$257 \mathrm{~W}:$ Okay.

$258 \mathrm{~J}$ : Very good. I feel really good about that.

$259 \mathrm{~W}$ : Okay. But don't forget the other stuff, because when you go back, and actually make a decision, lets suppose he's clean for a year, he could still go off and have the drugs a day after you go with him. You need to be prepared for that. You need to deal with all these other issues we're talking about. But it seems to me as if you are willing to give up a whole big life to a man who takes substances, you know, as soon as he gets angry. You see.

$260 \mathrm{~J}$ : Uh huh.

$261 \mathrm{~W}$ : Now, you know....I mean...

$262 \mathrm{~J}$ : And he is in debt big time, and my husband ...you know...has got a fair amount of money.

$263 \mathrm{~W}$ : Yeah exactly.

$264 \mathrm{~J}$ : That's another big thing.

$265 \mathrm{~W}$ : Maybe you also need to ask him...that again, the other thing is that maybe I need to see evidence that you are being more responsible with your money. Is living with somebody who's responsible important to you?

$266 \mathrm{~J}$ : Yeah I think so.

267 TAPE CUTS OUT HERE 